\title{
Fe-bearing $\mathrm{MgSiO}_{3}$ perovskite up to the Earth's lower mantle conditions
}

\author{
C. FANG $^{1} \&$ R. AHUJA ${ }^{1}$ \\ ${ }^{1}$ Condensed Matter Theory Group, Department of Physics and Astronomy, Uppsala University, \\ Box 516, S-751 20, Uppsala, Sweden. \\ rajeev@fysik.uu.se
}

Recibido: $17 / 05 / 2011$

Aceptado: 13/07/2011

\begin{abstract}
We investigated structural and electronic behaviors of $\mathrm{Fe}-\mathrm{MgSiO}_{3}$ under pressure up to that in the Earth's lower mantle using the first-principles theory. The $\mathrm{Fe}-\mathrm{MgSiO}_{3}$ crystals have phase transform from the orthorhombic perovskite $(\mathrm{OPv})$ structure into the orthorhombic post-perovskite $(\mathrm{OPPv})$ phase and the transition pressure decreasing with increasing Fe concentration. Electronic transitions occur in the pressure range of about 70 to $90 \mathrm{GPa}$ for an $(\mathrm{Mg}, \mathrm{Fe})(\mathrm{Si}, \mathrm{Fe}) \mathrm{O}_{3} \mathrm{OPv}$ crystal, in which the moment of the $\mathrm{Fe}^{4+}$ ion decreases gradually to zero at which the magnetic moment of the $\mathrm{Fe}^{2+}$ ion becomes zero. That electronic transition provides the possible mechanism to understand experiments.
\end{abstract}

Keywords: $\mathrm{Fe}-\mathrm{MgSiO}_{3}$, pressure, Earth's lower mantle, first-principles theory.

\section{Perovskita $\mathrm{MgSiO}_{3}$ con hierro bajo las condiciones del manto inferior de la Tierra}

\section{Resumen}

Se ha investigado el comportamiento electrónico y estructural de $\mathrm{Fe}-\mathrm{MgSiO}_{3}$ bajo presiones que llegan a la del manto inferior de la Tierra, usando la teoría de primeros principios. Los cristales de Fe$\mathrm{MgSiO}_{3}$ experimentan cambio de fase desde una estructura perovskita ortorrómbica $(\mathrm{OPv})$ hasta una fase de post-perovskita ortorrómbica $(\mathrm{OPPv})$, con una disminución de la presión de transición con el aumento de la concentración de $\mathrm{Fe}$. Las transiciones electrónicas tienen lugar en un rango de presión de unos 70 a $90 \mathrm{GPa}$ para un cristal $\mathrm{OPv}$ de $(\mathrm{Mg}, \mathrm{Fe})(\mathrm{Si}, \mathrm{Fe}) \mathrm{O}_{3}$, en el cual el momento del ion $\mathrm{Fe}^{4+}$ disminuye gradualmente a cero y el momento magnético del ion $\mathrm{Fe}^{2+}$ pasa a ser cero. Esa transición electrónica proporciona el posible mecanismo para entender los experimentos.

Palabras clave: $\mathrm{Fe}-\mathrm{MgSiO}_{3}$, presión, manto inferior de la Tierra, teoría de primeros principios.

\section{Referencia normalizada}

Fang, C., Ahuja, R., (2011). Fe-bearing $\mathrm{MgSiO}_{3}$ perovskite up to the Earth's lower mantle conditions. Física de la Tierra Vol. 23 Núm. 1 (2011): 43-49

The Earth is formed as a series of chemically distinct concentric shells and understanding structure, chemical composition and dynamics of these shells or layers is the cornerstone of modern Earth sciences. The mantle which extends from near the surface to the depth of $2900 \mathrm{~km}$, formed from mainly magnesium and silicate minerals bearing with $\mathrm{Fe}, \mathrm{Ca}$ and $\mathrm{Al}$. The structural properties of pure $\mathrm{MgSiO}_{3}$ is now well understood but the effect of impurity such as Fe is not very well known and also there exist some contradictions in the results obtained by the recent experiments. Fe is one of the abundant metals in the Earth's core and exists as impurity in mantle silicate minerals. Thus, the magnetic properties of iron impurity in 
silicate minerals play a crucial role in determining the properties of Earth's mantle mineral such as rheology, electrical and thermal properties etc. As the most abundant component in the Earth's lower mantle, $\mathrm{MgSiO}_{3}$ of pure composition as well as the composition containing $\mathrm{Fe}$ has been intensively studied for several decades (Mao et al., 2004; Mao et al., 2005; Jackson et al., 2005; Badro et al., 2003; Cohen et al., 1997). Mao et al., 2004-2005 reported their results of high-pressure experiments on compounds with the chemical formula $\left(\mathrm{Mg}_{1-\mathrm{x}} \mathrm{Fe}_{\mathrm{x}}\right) \mathrm{SiO}_{3}$ ( $\mathrm{x}=0.12$ to 1.00). They found that all samples convert entirely or partially into the OPPv structure at high pressures and the transition pressure decreases with increasing the concentration of Fe in the samples (Mao et al., 2005). Meanwhile, much attention has been paid to the electronic behaviors of the Fe dissolving the $\mathrm{MgSiO}_{3}$ crystals. From Xray emission spectroscopy, Badro, et al., 2003 discovered two electronic transitions of $\left(\mathrm{Mg}_{1-\mathrm{x}} \mathrm{Fe}_{\mathrm{x}}\right) \mathrm{SiO}_{3}(\mathrm{x}=0.10) \mathrm{OPv}$ at pressures about 70 and $110 \mathrm{GPa}$. Using a synchrotron Mössbauer spectroscopy technique, Jackson et al., 2005 studied the electronic environments of the $\mathrm{Fe}$ ions in the $\left(\mathrm{Mg}_{1-\mathrm{x}} \mathrm{Fe}_{\mathrm{x}}\right) \mathrm{SiO}_{3}(\mathrm{x}=0.05$ and 0.10$)$ samples at pressures up to about $120 \mathrm{GPa}$ and concluded that there are two kinds of $\mathrm{Fe}^{2+}$ ions and one kind of $\mathrm{Fe}^{3+}$ ions (the so-called 'three-double' model) in the samples. They also found that pressure alone does not alter the valence states of the iron ions in $(\mathrm{Mg}, \mathrm{Fe}) \mathrm{SiO}_{3} \mathrm{OPv}$ samples. Around $70 \mathrm{GPa}$, they observed a change in the isomer shift, which was interpreted as an electronic transition.

Theoretical efforts have also been made to build up a clear picture of the electronic properties of the $\mathrm{Fe}$ dissolving $\mathrm{MgSiO}_{3}$ crystals under pressure. Mao et al., 2005 also reported the results of their first-principles calculations for $\left(\mathrm{Mg}_{1}\right.$ $\left.{ }_{x} \mathrm{Fe}_{\mathrm{x}}\right) \mathrm{SiO}_{3}(\mathrm{x}=0.5,1.0)$ and found that the $\mathrm{OPv}$ with $\mathrm{x}=0.5$ transfer to its $\mathrm{OPPv}$ at about $63 \mathrm{GPa}$ and for $\mathrm{FeSiO}_{3}(\mathrm{x}=1.00)$ the $\mathrm{OPPv}$ form is more stable at all pressure. However, there is no report on theoretical studies of the $\mathrm{FeSiO}_{3} \mathrm{Pvs}$ and PPvs with dilute Fe concentrations. Here, we present the results of first-principles calculations of the dilute $\mathrm{Fe}$ dissolving $\mathrm{MgSiO}_{3}$ crystals under pressure. The influences of pressure on the lattices and on chemical bonding, as well on the electronic behaviors are investigated.

The forms of $\mathrm{Fe}$ existing in the $\mathrm{MgSiO}_{3}$ samples are still far from clear. Different forms and valences of the $\mathrm{Fe}$ ions in the $\mathrm{MgSiO}_{3}$ samples were suggested (Jackson et al., 2005; Cohen et al., 1997). We have studied one possible type of the Fe dissolving in $\mathrm{MgSiO}_{3}$ : Replacements of one $\mathrm{Mg}$ and $\mathrm{Si}$ pair by two $\mathrm{Fe}$ atoms to form a $\left(\mathrm{Mg}_{1-\mathrm{x}} \mathrm{Fe}_{\mathrm{x}}\right)\left(\mathrm{Si}_{1-\mathrm{x}} \mathrm{Fe}_{\mathrm{x}}\right) \mathrm{O}_{3} \quad(\mathrm{x}=0.0625)$. In the calculations a supercell of $2 a_{\text {opv }} \times 2 b_{\text {opv }} \times 1 c_{\text {opv }}$ and of $4 a_{\text {oppv }} \times 1 b_{\text {oppv }} \times 1 c_{\text {oppv }}$ was employed for the OPv and OPPv structure, respectively. Theoretical calculations were carried out using the VASP code, Vienna ab initio simulation program (Kresse et al., 1993; Kresse et al., 1994; Blöchl et al., 1994; Kresse et al., 1999). Both lattice parameters and internal coordinates of the atoms have been fully relaxed.

Experiments have showed that the Fe ions in the $\mathrm{MgSiO}_{3}$ samples exist in more complicated forms. Different possibilities for the forms of complicated Fe clusters existing in the $\mathrm{MgSiO}_{3}$ crystals could not be excluded. Here we suggest a simple 
configuration by replacing a Mg-Si pair by two Fe ions to obtain $\left(\mathrm{Mg}_{1-\mathrm{x}} \mathrm{Fe}_{\mathrm{x}}\right)\left(\mathrm{Si}_{1-}\right.$ $\left.{ }_{x} \mathrm{Fe}_{\mathrm{x}}\right) \mathrm{O}_{3}(\mathrm{x}=0.0625)$ in chemical formula.

First we tested the effects of $\mathrm{Fe}(\mathrm{Si})-\mathrm{Fe}(\mathrm{Mg})$ distances. The calculations showed that in both $\mathrm{OPv}$ and $\mathrm{OPPv}$ the two iron ions prefer to stay closer, in line with the results of dilute $\mathrm{Mn}$ in $\mathrm{ZnO}$ crystal (Sharma et al., 2003). Therefore we report the results for $\left(\mathrm{Mg}_{1-\mathrm{x}} \mathrm{Fe}_{\mathrm{x}}\right)\left(\mathrm{Si}_{1-\mathrm{x}} \mathrm{Fe}_{\mathrm{x}}\right) \mathrm{O}_{3}(\mathrm{x}=0.0625) \mathrm{OPPv}$ and $\mathrm{OPv}$ with these shortest $\mathrm{Fe}(\mathrm{Si})-\mathrm{Fe}(\mathrm{Mg})$ distances. The transition pressure at zero $\mathrm{K}$ is calculated to be about $24 \mathrm{GPa}$.

The calculated total DOSs close to the Fermi level for $\left(\mathrm{Mg}_{1-\mathrm{x}} \mathrm{Fe}_{\mathrm{x}}\right)\left(\mathrm{Si}_{1-\mathrm{x}} \mathrm{Fe}_{\mathrm{x}}\right) \mathrm{O}_{3}$ $(\mathrm{x}=0.0625) \mathrm{OPv}$ crystal at about $0,70,81$ and $110 \mathrm{GPa}$ are presented in Figure 1. The total DOS for the OPPv at $0 \mathrm{GPa}$ is included for comparison. At ambient condition for the $\left(\mathrm{Mg}_{1-\mathrm{x}} \mathrm{Fe}_{\mathrm{x}}\right)\left(\mathrm{Si}_{1-\mathrm{x}} \mathrm{Fe}_{\mathrm{x}}\right) \mathrm{O}_{3}(\mathrm{x}=0.0625) \mathrm{OPv}$ the splitting of the Fe 3d orbitals is very apparent. For the spin-up electrons the Fermi level is at the energy gap (about $1.6 \mathrm{eV}$ ), while for the spin-down electrons, the Fermi level is between two peaks. For the $\mathrm{Fe}$ at the $\mathrm{Mg}$ site, the spin-up 3d orbitals are fully occupied while the spin-down $3 \mathrm{~d}$ orbitals are occupied by one electron. For the Fe at the site, three $3 \mathrm{~d}$ orbitals are occupied by the spin-up electrons, while only one electron occupies the spin-down $3 \mathrm{~d}$ orbitals. The total magnetic moment for the $\mathrm{OPv}$ is $6 \mu_{\mathrm{B}} /$ cell, indicating the $\mathrm{Fe}^{2+}\left(3 \mathrm{~d}^{6}\right)-\mathrm{Fe}^{4+}\left(3 \mathrm{~d}^{4}\right)$ pair. However, the $\mathrm{Fe}-\mathrm{Fe}$ interaction can also been seen when we compare the DOS of $\left(\mathrm{Mg}_{1-\mathrm{x}} \mathrm{Fe}_{\mathrm{x}}\right)\left(\mathrm{Si}_{1-\mathrm{x}} \mathrm{Fe}_{\mathrm{x}}\right) \mathrm{O}_{3}(\mathrm{x}=0.0625) \mathrm{OPv}$ (Figure 1) with those of $\left(\mathrm{Mg}_{1-\mathrm{x}} \mathrm{Fe}_{\mathrm{x}}\right) \mathrm{SiO}_{3}$ and $\mathrm{Mg}\left(\mathrm{Si}_{1-\mathrm{x}} \mathrm{Fe}_{\mathrm{x}}\right) \mathrm{O}_{3}(\mathrm{x}=0.0625)$ OPvs. The Fermi level is at the fall of the two peaks for the spin-down electrons, which is caused by the local relaxation and the $\mathrm{Fe}-\mathrm{Fe}$ bonding (bond of about $2.8 \AA$ ). It is also shown that with increasing pressure, the structure distortion causes the increasing width of the $3 \mathrm{~d}$ bands. It is also noted as shown in Figure 1, at about $70 \mathrm{GPa}$, the three lower bands for the spin-down electrons re-constructed and the Fermi level is at the peak of the lowest band. Further increasing pressure causes change of the electronic structure. At about $82 \mathrm{GPa}$, the $\left(\mathrm{Mg}_{1-\mathrm{x}} \mathrm{Fe}_{\mathrm{x}}\right)\left(\mathrm{Si}_{1-\mathrm{x}} \mathrm{Fe}_{\mathrm{x}}\right) \mathrm{O}_{3}(\mathrm{x}=0.0625) \mathrm{OPv}$ becomes anti-ferrimagnetic (Figure 1). The $\mathrm{Fe}$ at the $\mathrm{Mg}$ site is still almost fully occupied, however, the $\mathrm{Fe}$ at the Si site has smaller magnetic moment (about $\left.0.5 \mu_{\mathrm{B}}\right) \mu_{\mathrm{B}} / \mathrm{Fe}$. That results the total magnetic moment to be about $3.5 \mu_{\mathrm{B}}$ for the $\left(\mathrm{Mg}_{1-\mathrm{x}} \mathrm{Fe}_{\mathrm{x}}\right)\left(\mathrm{Si}_{1-}\right.$ $\left.{ }_{\mathrm{x}} \mathrm{Fe}_{\mathrm{x}}\right) \mathrm{O}_{3}(\mathrm{x}=0.0625) \mathrm{OPv}$ at about $82 \mathrm{GPa}$. At pressure higher than about $90 \mathrm{GPa}$, the $\mathrm{OPv}$ becomes non-magnetic, as shown in Figure 1 at pressure at $110 \mathrm{GPa}$. Strong $\mathrm{Fe}-\mathrm{Fe}$ interaction in the $\left(\mathrm{Mg}_{1-\mathrm{x}} \mathrm{Fe}_{\mathrm{x}}\right)\left(\mathrm{Si}_{1-\mathrm{x}} \mathrm{Fe}_{\mathrm{x}}\right) \mathrm{O}_{3}(\mathrm{x}=0.0625) \mathrm{OPPv}$ can be seen as we compare its DOS with those of the $\left(\mathrm{Mg}_{1-\mathrm{x}} \mathrm{Fe}_{\mathrm{x}}\right) \mathrm{SiO}_{3}(\mathrm{x}=0.0625) \mathrm{OPPv}$ and the $\mathrm{Mg}$ $\left(\mathrm{Si}_{1-\mathrm{x}} \mathrm{Fe}_{\mathrm{x}}\right) \mathrm{O}_{3}(\mathrm{x}=0.0625) \mathrm{OPPv}$. The spin-up $3 \mathrm{~d}$ orbitals of the Fe at $\mathrm{Mg}$ site are fully occupied, while there are still some DOS in the spin-down direction below the Fermi level. Also at Fermi level, the DOSs are rather high. That is due to the short Fe-Fe distance (about $2.6 \AA$ ) in the compound. However, The calculations shown that the two Fe ions in the OPPv crystal have magnetic moments of $6 \mu_{\mathrm{B}}\left(4 \mu_{\mathrm{B}}\right.$ per $\mathrm{Fe}^{2+}$ and $2 \mu_{\mathrm{B}}$ per $\mathrm{Fe}^{4+}$ ) at pressure up to about $150 \mathrm{GPa}$, indicating no electronic transitions. That is corresponding to the similarities of the local bonds of the $\mathrm{Fe}$ ions. However, complicated electronic behaviors were found for the OPv crystal. The calculated energy differences (total magnetic moments vs. non-magnetic status) for 
the $\mathrm{OPv}$ are shown in Table 1. At low pressures (lower than about $72 \mathrm{GPa}$ ), the calculations showed that the ferromagnetic ordering with total magnetic moment of $6 \mu_{\mathrm{B}}\left(4\right.$ for $\mathrm{Fe}^{2+}$ and 2 for $\left.\mathrm{Fe}^{4+}\right)$ is more stable than the other states.

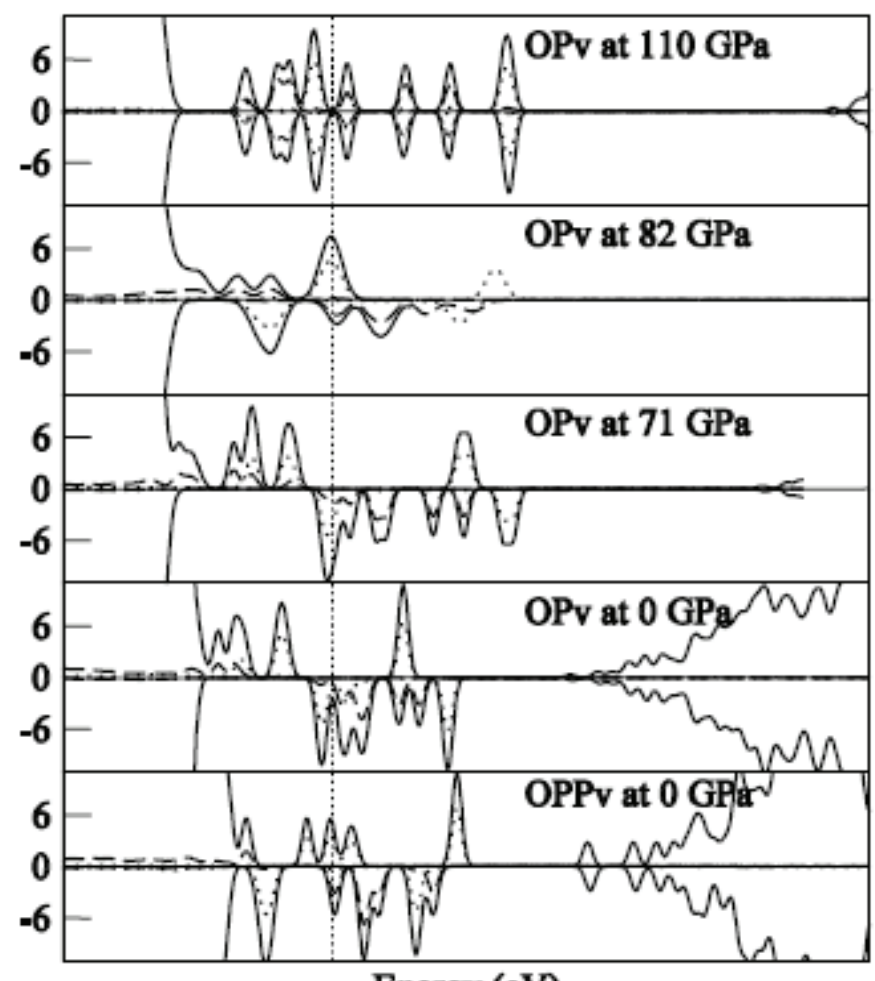

Energy (eV)

Fig. 1. OPv-( $\left.\mathrm{Fe}_{0.0625} \mathrm{Mg}_{0.9375}\right)\left(\mathrm{Fe}_{0.0625} \mathrm{Si}_{0.9375}\right) \mathrm{O}_{3}$ : (a) at $110 \mathrm{GPa}$, (b) at $82 \mathrm{GPa}$, (c) at $0 \mathrm{GPa}$ (d) OPPv- $\left(\mathrm{Fe}_{0.0625} \mathrm{Mg}_{0.9375}\right)\left(\mathrm{Fe}_{0.0625} \mathrm{Si}_{0.9375}\right) \mathrm{SiO}_{3}$ at $0 \mathrm{GPa}$. The filled black lines represent the total DOS, the dots for the Fe $3 \mathrm{~d}$ at the Si site and the short-lines the Fe $3 \mathrm{~d}$ at the $\mathrm{Mg}$ site.

At about $82 \mathrm{GPa}$ the calculations with fully relaxation of the coordinates of atoms and spin-polarization of $\mathrm{Fe}$ ions result in a ferri-magnetic ordering with a total magnetic moment of $3.5 \mu_{\mathrm{B}}$ in which the $\mathrm{Fe}^{2+}$ has $4 \mu_{\mathrm{B}}$ and the $\mathrm{Fe}^{2+}$ ion is partially quenched with the moment of about $-0.5 \mu_{\mathrm{B}}$. The calculated energy of the ferromagnetic status is slightly higher (about $0.01 \mathrm{eV}$ ) than that of the non-magnetic status. Above $91 \mathrm{GPa}$, the Fe ions are in the non-magnetic status. However, between about $78 \mathrm{GPa}$ to $90 \mathrm{GPa}$, the energies calculated energies for different mag- 
netic moments are very close, as shown in Table 1, which indicates coexistence of multiple-magnetic status.

Table 1. Energy differences $\left(E_{\mathrm{i}}\right.$, where $i$ represents the value of magnetic moment per $\left.\mathrm{Fe}^{\mathrm{i}+}\right)$ for different spin-polarization states of $\mathrm{Fe}$ ions relative to that of $\mathrm{Fe}^{4+}$ in $\left(\mathrm{Fe}_{\mathrm{x}} \mathrm{Mg}_{1-\mathrm{x}}\right)\left(\mathrm{Fe}_{\mathrm{x}} \mathrm{Si}_{1-}\right.$ х) $\mathrm{O}_{3}(\mathrm{x}=0.0625) \mathrm{OPv}$.

\begin{tabular}{|c|c|c|c|c|c|c|}
\hline $\boldsymbol{P}(\boldsymbol{G P a})$ & $\mathbf{2 8 . 6}$ & $\mathbf{7 1 . 8}$ & $\mathbf{8 0 . 8}$ & $\mathbf{9 2 . 3}$ & $\mathbf{9 7}$ & $\mathbf{1 0 6}$ \\
\hline$\Delta E(\mathrm{eV})$ & & & & & & \\
$E_{2}-E_{0}$ & -1.25 & -0.50 & +0.08 & +0.11 & +0.16 & +0.18 \\
$E_{4}-E_{0}$ & -1.52 & -0.56 & +0.05 & +0.12 & +0.13 & +0.37 \\
$E_{6}-E_{0}$ & -1.70 & -0.64 & +0.02 & +0.07 & +0.21 & +0.35 \\
\hline
\end{tabular}

Our calculations showed that electronic transitions were found in the $(\mathrm{Mg}, \mathrm{Fe})(\mathrm{Si}, \mathrm{Fe}) \mathrm{O}_{3} \mathrm{OPv}$ with $\mathrm{Fe}^{2+}-\mathrm{Fe}^{4+}$ pairs. Combined with calculated results and experimental data, it is reasonable to suggest that in most Fe dissolving $\mathrm{MgSiO}_{3}$ high-pressure-prepared samples, Fe ions exist mainly at dodecahedral $(\mathrm{Mg})$ sites, as well as at dodecahedral $(\mathrm{Mg})$ and octahedral $(\mathrm{Si})$ sites to form $\mathrm{Fe}^{2+}-\mathrm{Fe}^{4+}$ pairs or such clusters. The $\mathrm{Fe}^{(2+\delta)+}-\mathrm{Fe}^{(4-\delta)+}$ pairs and $\mathrm{Fe}^{2+}$ at the $\mathrm{Mg}$ sites would result in the 'double triplet' model proposed by Jackson et al., 2005. Such mixed $\mathrm{Fe}^{2+}$ ions and $\mathrm{Fe}^{2+}-\mathrm{Fe}^{4+}$ clusters would cause distortion of the Si-O network in the OPVs and OPPvs, as well as the local symmetry and structure of the Fe ions. Due to the strong itinerant nature of the $\mathrm{Fe}^{2+}-\mathrm{Fe}^{4+} 3 \mathrm{~d}$ electrons in the $\mathrm{OPvs}$, the transition pressure lowers down with increasing Fe concentration.

Badro et al., 2003 discovered two electronic transitions at about $70 \mathrm{GPa}$ (highspin to mixed spin) and at about $110 \mathrm{GPa}$ (mixed spin to low-spin). Our calculations showed that at about $70 \mathrm{GPa}$, the magnetic moment of the $\mathrm{Fe}^{4+}$ ions in the pair $\mathrm{Fe}^{2+}$ $\mathrm{Fe}^{4+}$ clusters decreases first. At about $81 \mathrm{GPa}$, the magnetic moments of both $\mathrm{Fe}^{2+}$ and $\mathrm{Fe}^{4+}$ ions in the $\mathrm{Fe}^{2+}-\mathrm{Fe}^{4+}$ clusters are quenched to zero. The small energy differences among the different magnetic configurations also indicate the coexistence of multiple-magnetic status of the Fe-ion clusters in a large transition pressure range. The pressure large range in the electronic transitions may originate from also inhomogeneous of $\mathrm{Fe}$ distributions in the samples. It is also noted that our calculations showed a low transition pressure (about $24 \mathrm{GPa})$ from the $(\mathrm{Mg}, \mathrm{Fe})(\mathrm{Si}, \mathrm{Fe}) \mathrm{O}_{3}$ $\mathrm{OPv}$ to the $\mathrm{OPPv}$ form, which is much higher than the transition range ( $>90 \mathrm{GPa})$ for $\mathrm{x}=12.5 \%\left(\mathrm{Mg}_{1-\mathrm{x}} \mathrm{Fe}_{\mathrm{x}}\right) \mathrm{SiO}_{3}$ (Mao et al., 2005). That is partially because that it needs to overcome a high barrier to finish such transitions. It also indicates that $\mathrm{Fe}$ ions in $\mathrm{MgSiO}_{3}$ exist in more complicated forms.

In summary, we have performed theoretical calculations for the behaviors of $\mathrm{Fe}$ in $\mathrm{MgSiO}_{3}$ crystals under pressure up to that in the Earth's lower mantle using the DFT-GGA method. The calculations showed that the transition pressure from the $\mathrm{OPv}$ to the $\mathrm{OPPv}$ phase decreases as the $\mathrm{Fe}$ concentration increases. Electronic transitions have been found for the $(\mathrm{Mg}, \mathrm{Fe})(\mathrm{Si}, \mathrm{Fe}) \mathrm{O}_{3} \mathrm{OPv}$ with $\mathrm{Fe}^{2+}-\mathrm{Fe}^{4+}$ pair-like 
clusters. In such OPvs multiple magnetic moments may exist in a large pressure range (e.g. 78 to $110 \mathrm{GPa}$ ). Based on our calculations, we assume that in the highpressure and high-temperature prepared $\mathrm{Fe}-\mathrm{MgSiO}_{3}$ crystals, $\mathrm{Fe}$ ions are positioned at the $\mathrm{Mg}$ sites, as well as at the Si-Mg sites, forming $\mathrm{Fe}^{2+}$ and $\mathrm{Fe}^{(2+\delta)^{+}}-\mathrm{Fe}^{(4-\delta)^{+}}$type clusters.

\section{References}

BADRO, J., RUEFF, J.-P., VANO, G., MONACO, G., FIGUET, G. \& GUYOT, F. (2003). Iron partitioning in Earth's mantle: Toward a deep lower mantle discontinuity. Science, $305,383$.

doi:10.1126/science.1098840;

http://dx.doi.org/10.1126/science. 1098840

BLÖCHL, P. E. (1994). Projector augmented-wave method. Phys. Rev. B, 50, 17953.

doi:10.1103/PhysRevB.50.17953; http://dx.doi.org/10.1103/PhysRevB.50.17953

COHEN, R. E., MAZIN, I. I., ISAAK, D. G. (1997). Magnetic collapse in transition metal oxides at high pressure: Implications for the Earth. Science, 275, 654.

doi:10.1126/science.275.5300.654;

http://dx.doi.org/10.1126/science.275.5300.654

JACKSON, J. M., STURHAHN, W., SHEN, G. Y., ZHAO, J. Y., HU, M. Y., ERRANDONA, D., BASS, J. D., \& FEI, Y. W. (2005). A synchrotron Mossbauer spectroscopy study of $(\mathrm{Mg}, \mathrm{Fe}) \mathrm{SiO}_{3}$ perovskite up to $120 \mathrm{GPa}$. Am. Miner., 90, 199. doi:10.2138/am.2005.1633; http://dx.doi.org/10.2138/am.2005.1633

KRESSE, G., \& HAFNER, J. (1993). Ab initio molecular dynamics for liquid metals. Phys. Rev. $B, 47,558$.

doi:10.1103/PhysRevB.47.558;

http://dx.doi.org/10.1103/PhysRevB.47.558

KRESSE, G., \& HAFNER, J. (1994). Ab initio molecular-dynamics simulation of the liquid-metal-amorphous-semiconductor transition in germanium. Phys. Rev. B, 49, 14251.

doi:10.1103/PhysRevB.49.14251;

http://dx.doi.org/10.1103/PhysRevB.49.14251

KRESSE, G. \& HAFNER, J. (1999). From ultrasoft pseudopotentials to the projector augmented-wave method. Phys. Rev. B, 59, 1758.

doi:10.1103/PhysRevB.59.1758;

http://dx.doi.org/10.1103/PhysRevB.59.1758

MAO, W. L., SHEN, G. Y., PRAKAPENKA, V. B., MENG, Y., CAMPBELL, A. J., HEINZ, D. L., SHU, J. F., HEMLEY, R. L., \& MAO, H.-K. (2004). Ferromagnesian postperovskite silicates in the D" layer of the Earth. Proceedings of the National Academy of Sciences (PNAS), 101, 15867.

doi:10.1073/pnas.0407135101;

http://dx.doi.org/10.1073/pnas.0407135101

MAO, W. L., MENG, Y., SHEN, G. Y., PRAKAPENKA, V. B., CAMPBELL, A. J., HEINZ, D. L., SHU, J. F., CARACAS, R., COHEN, R. E., FEI, Y. W., HEMLEY, R. L., 
\& MAO, H.-K. (2005). Iron-rich silicates in the Earth's D' layer. Proceedings of the National Academy of Sciences (PNAS), 102, 9751.

doi:10.1073/pnas.0503737102;

http://dx.doi.org/10.1073/pnas.0503737102

SHARMA, P., GUPTA, A., RAO, K. V., OWENS, F.J., SHARMA, R., AHUJA, R., OSORIO GUILLEN, J.M., JOHANSSON, B., \& GEHRING, G.A. (2003). Ferromagnetism above room temperature in bulk and transparent thin films ofMn-doped $\mathrm{ZnO}$. $\mathrm{Na}$ ture-Materials, 2, 673.

doi:10.1038/nmat984;

http://dx.doi.org/10.1038/nmat984 